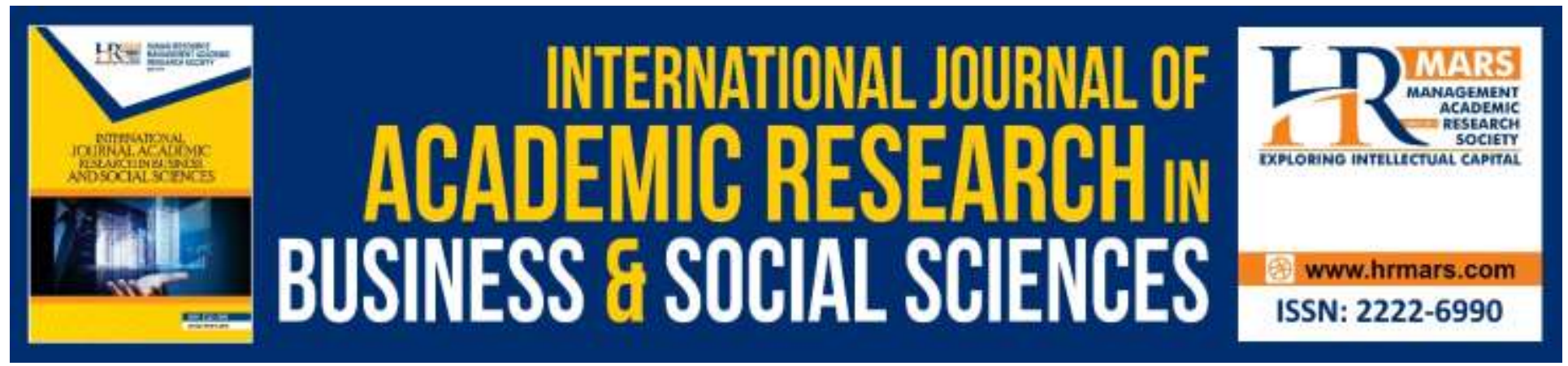

\title{
Exploring and Analyzing (Go) Decision for Burger Makers to Enter Singaporean Market
}

\author{
Ahmad A. Hamzeh, Abdallah Q. Bataineh
}

To Link this Article: http://dx.doi.org/10.6007/IJARBSS/v9-i11/6633

DOI: 10.6007/IJARBSS/v9-i11/6633

Received: 02 November 2019, Revised: 19 November 2019, Accepted: 30 November 2019

Published Online: 02 December 2019

In-Text Citation: (Hamzeh \& Bataineh, 2019)

To Cite this Article: Hamzeh, A. A., \& Bataineh, A. Q. (2019). Exploring and Analyzing (Go) Decision for Burger Makers to Enter Singaporean Market. International Journal of Academic Research in Business and Social Sciences, 9(11), 1050-1062.

Copyright: (C) 2019 The Author(s)

Published by Human Resource Management Academic Research Society (www.hrmars.com)

This article is published under the Creative Commons Attribution (CC BY 4.0) license. Anyone may reproduce, distribute, translate and create derivative works of this article (for both commercial and non-commercial purposes), subject to full attribution to the original publication and authors. The full terms of this license may be seen at: http://creativecommons.org/licences/by/4.0/legalcode

Vol. 9, No. 11, 2019, Pg. 1050 - 1062

http://hrmars.com/index.php/pages/detail/IJARBSS

JOURNAL HOMEPAGE

Full Terms \& Conditions of access and use can be found at http://hrmars.com/index.php/pages/detail/publication-ethics 


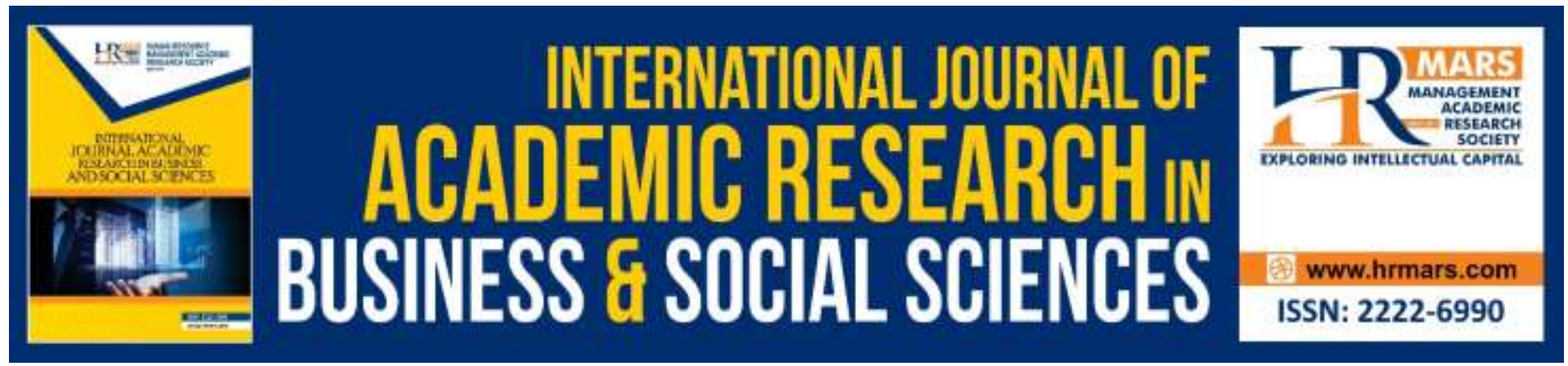

\title{
Exploring and Analyzing (Go) Decision for Burger Makers to Enter Singaporean Market
}

\author{
Ahmad A. Hamzeh \\ MBA Student University of Wails, Trinity Saint David, UK \\ Email: ahmad.haamzeh@gmail.com
}

Abdallah Q. Bataineh

Associate Professor, Department of Marketing, Middle East University, Amman, Jordan

E-mail: abataineh@meu.edu.jo

\begin{abstract}
Singapore is a world-class city to work, study, live and play. This globally connected, multicultural, cosmopolitan city-state offers a helpful environment to numerous industries, including creative and knowledge-driven ones. The purpose of this research is to understand and analyze the importance of both external and internal factors affecting international marketing strategies along with detail analysis of the international marketing campaign strategies. The chosen Jordanian organization which is supposed to establish its business in Singapore is (Burger Makers Company). In this research, various external and internal factors that will affect the international expansion of Burger Makers have been analyzed. Along with this, several strategies has been developed for the prelaunch campaign of the company in Singapore. The results showed that Burger Makers has a great potential to enter the Singaporean market by deeply analyzing the Singaporean market and implementing pre and post international marketing strategies in order to establish brand awareness and expand the market share in the future.

Keywords: International Market Analysis, SWOT Analysis, 4P's, Strategic Marketing Campaign, Burger Makers, Jordan, Singapore.
\end{abstract}

\section{Introduction}

At the present time, globalization has removed the geographic borders and restrictions between countries, which provided consumers with limitless ranges of products and services, and made the entire world as a giant market (Bataineh and Alfalah, 2015). International marketing is a crucial for an organization which is planning to expand its business across the world. In this era of globalization, every business organization is working on enhancing its business in the 
international market. Expansion of business in the international market not only results in increment of the amount of consumers in an organization but also enhances the revenue of the company eventually. However, before a company decides to go international and offer its products to a completely new market, every organization should perform thorough and adequate research to understand the potentiality of the chosen foreign market. An organization must conduct research to analyze the political, legal, economic and environmental structure and configuration of the market. Apart from that, a company needs to understand the potentiality and popularity of the existing competitors in that particular market (Solomon et al., 2014).

The international fast food industry is divided into type and service-type. In terms of type, the industry is segmented into steaks, burger sandwich, pizza, pasta, chicken, seafood and Asian food; however, burger/sandwich sector is predictable to hold a vital share in the global market, through amassed consumption among young consumers. While service type, it can be divided into (eat-in, take away, and drive-through, delivery and others). Noticeably, the delivery segments are substantially and make it a fertile ground to start-up companies.

Analyzing all the above mentioned factor will help the company to decide if the company has the potentiality to expand in the chosen global market. Besides conducting external analysis, a company needs to conduct internal analysis to understand its strengths weaknesses and potential threats that will impose impact on the company while expanding its business in the international market. Conducting of internal analysis also helps an organization to understand the opportunities that will help the organization to overcome its weakness and expand in the international market.

\section{Research Justification And Importance}

Singapore is considered to be one of the most developed food market in Asia. The fast food market of Singapore is continuously growing. According to marketing statistics, the fast food market value of Singapore in 2017 is approximately 1.16 billion U.S. dollar which is a huge amount compared to the other fast food markets of Asia (Gordon, 2012). Therefore it can be clearly understood that the decision of Burger Makers to expand its business to Singapore is justified. Considering the fact that Burger Makers is approaching the fast food market of Singapore it is crucial for the company to conduct the above mentioned external and internal analysis to understand the fast food market of Singapore and develop marketing strategies to ensure prosperity in the chosen fast food market. Besides that, the employees play strategic role in connecting and building robust relationships between consumers and organizations (Bataineh et al., 2017).

\section{Research Approach}

In order to conduct external and internal market analysis, it is very crucial to perform market auditing (Czinkota and Ronkainen, 2013). The Marketing audit may be defined as the comprehensive, systematic, evaluation, analysis and interpretation of the international market environment. It includes analysis of external and internal market, evolution of goals, strategies, principles in order to access the problematic areas, opportunities along with recommendation of 
an action plan in order to enhance the company's marketing performance. International marketing audits chiefly involves the following internal and external parameters:

\section{Internal Parameters}

The internal parameters of international market auditing involve marketing mix, labors, marketing team, machines and investment. In order to conduct internal auditing, an organization needs to inspect its current operations and processes like profits, costs, sales and others. This helps the company to know about the existing loopholes which in turn helps the company to develop strategies to close it (Armstrong, 2015). Therefore internal parameters of Market auditing help an organization to identify and overcome its shortcomings.

In order to conduct internal market analysis, the SWOT analysis model can be used. SWOT model is basically a marketing tool which is used to determine the strengths, weaknesses, opportunities and threats of an organization (Srdjevic et al., 2012). While strengths and weaknesses are the internal factors of the company which can be controlled by the company itself, opportunities of a particular organization in the international market are determined by certain external factors. The second marketing tool that can be used for internal analysis is the marketing mix Model. The Marketing mix is a crucial tool that helps the management of an organization to understand what the service or product can offer to the consumer of the international market. It also helps to management to plan for a successful product offering. The above mentioned tool is commonly executed with the help of $4 \mathrm{P}^{\prime} \mathrm{s}$ of marketing namely, Price, Product, Promotion and Place.

\section{External Parameter}

The external marketing audit includes positioning, segmentation, buying behavior, consumer believes of the chosen international market. In external audit the above mentioned factors are being assessed and detailed research are generated. Apart from these factors, the competitive environment as well as the economic environment of the specific market is also analyzed. In order to access these external factors, a common marketing tool known as the PESTLE model can be used. Besides that, in order to access the degree of competition in the market, Porter's five forces model can be used (Yüksel, 2012). While PESTLE Analysis is comprised of analysis of the Political, Economic, Social, Technological, Legal and Economic factors of the chosen international market, Porter's 5 forces Model majorly access threats from the substitution products, power of the suppliers, power of the buyers and threats from the new entrances in the chosen international market.

\section{Pestle Analysis}

In order to understand the political, economic, social, technological, legal and economic factors of the chosen international market, the management of Burger Makers should conduct PESTLE Analysis of the fast food industry of Singapore. 


\section{Political Analysis}

Political analysis involves governmental policies, laws and regulations of the country which imposes an effect on the business organizations of that specific country. Considering the fact that Singapore is a bureaucratic as well as a democratic nation, the political condition of the country is highly stable. In order to expand its business in the Singapore, Burger Makers must abide by the tax, food safety and health related regulations of Singapore.

\section{Economic Analysis}

Being a highly developed country, the economic condition of the fast food consumers in Singapore is stable. Besides that, being a famous tourist spot, Singapore can be considered as a potential market for fast food industry. According to a World Bank report Singaporean gross domestic product GDP in 2017 was 323.9 billion\$ and GDP per capita: 57,714.30\$ in the same year, however, the GDP growth rate: $3.6 \%$ and the Gross national income: 508.3 billion, which means that Singaporean market reflect remarkable economic progress and high opportunity to seize on. Moreover, Singapore's Economic Development Board (EDB) is highly encouraging investments from both local and multinational corporations, by offering remarkable incentives in funding research and development, tax consultations and rebates.

\section{Social Analysis}

Considering the fact that citizens of Singapore are getting more and more inclined towards healthy life style, Burger Makers should incorporate fast food products consisting of healthy ingredients in its menu list. Besides that, as fast food business is highly affected by the local taste and preferences, the mentioned company should incorporate local preferences in its menu list. Since the life style of the Singaporean citizens is fast, fast food products are preferred in Singapore due to its quick and easy deliverance (Baker and Saren, 2016). Likewise, to increase productivity, Singaporean government is working on people development, and motivating research and innovation, in order to take full advantage of of industrial transformation program.

\section{Technological Analysis}

Information technology (IT) impacts everything in the $21^{\text {st }}$ century, from business to daily life. In business setting, it shapes not only market and trade, but also the whole system which organizations implement their marketing strategies (Shoter et al., 2016). Singapore aims to be a world-class electronics hub, creating manufacturing solutions and producing high value-added components for the global market. Being a technologically advanced country, Singapore remains up-to-date with the latest technologies. This will help the Burger Makers to maintain the quality and service of their product equal in every outlets along with fast deliverance of the products. It also ensure both online and offline advertisement of the Company.

\section{Legal Analysis}

In order to create a balance between rights protection for copyright investors and increase public access to intellectual property, Singapore government made both intellectual and copyright laws 
consistent with original philosophies in international laws. On the other hand, Singapore has strict health laws that affect the fast food industries of Singapore. Besides that, the country has several labor laws which must be abided by the burger makers to establish a successful business in the country.

\section{Environmental Analysis}

Being a developed country, Singapore imposes several laws to maintain the cleanliness and environmental safety of the country. Therefore in addition to the above mentioned laws, the Burger Makers must abide by the environmental law to establish its business in Singapore.

\section{Porters Five Forces Analysis}

In order to understand the degree of competition in the Singaporean industry, Porter five forces analysis have been conducted bellow:

Table 1: Five Forces Analysis Of Burger Makers

\begin{tabular}{|l|l|}
\hline $\begin{array}{l}\text { Bargaining power of } \\
\text { the Buyers }\end{array}$ & $\begin{array}{l}\text { Since a lot of fast food brands are present in the Singaporean market, } \\
\text { the power of the consumers is pretty high in Singapore (Dobbs, 2014). }\end{array}$ \\
\hline $\begin{array}{l}\text { Bargaining power of } \\
\text { the suppliers }\end{array}$ & $\begin{array}{l}\text { Considering the fact that the chief ingredients of the fast food industry } \\
\text { are readily available in the Singaporean market, the power of the } \\
\text { supplier is pretty low there }\end{array}$ \\
\hline $\begin{array}{l}\text { Threat of substitute } \\
\text { products }\end{array}$ & $\begin{array}{l}\text { Considering the fact that consumers are inclined towards healthy } \\
\text { foods, the threat of substitute products is high for Singaporean fast } \\
\text { food industry. }\end{array}$ \\
\hline Competitive rivalry & $\begin{array}{l}\text { Since a huge number of fast food companies are present in Singapore, } \\
\text { a high amount of rivalry is present between the existing fast-food } \\
\text { brands. }\end{array}$ \\
\hline $\begin{array}{l}\text { Threat from new } \\
\text { entrance }\end{array}$ & $\begin{array}{l}\text { Due to high amount of entry cost in the fast food industry and the high } \\
\text { competition, the threat of new entrants is low in Singaporean market. }\end{array}$ \\
\hline
\end{tabular}

\section{Internal Analysis Of Burger Makers}

In order to understand and solve the loopholes of its management and develop strategies to expand in business in the fast food market of Singapore, 4P marketing mix and SWOT analysis of Burger Makers has been performed bellow: 
INTERNATIONAL JOURNAL OF ACADEMIC RESEARCH IN BUSINESS AND SOCIAL SCIENCES

Vol. 9, No. 11, November, 2019, E-ISSN: 2222-6990 @ 2019 HRMARS

Table 2: 4P Marketing Mix Of Burger Makers

\begin{tabular}{|c|c|c|c|}
\hline Product & Place & Price & Promotion \\
\hline $\begin{array}{l}\text { Considering the fact } \\
\text { that Burger Makers is } \\
\text { going to establish } \\
\text { business in a country } \\
\text { where the consumers } \\
\text { are inclined towards a } \\
\text { healthy lifestyle, the } \\
\text { company should } \\
\text { incorporate healthy } \\
\text { products like brown } \\
\text { rice and spinaches in } \\
\text { its fast food products }\end{array}$ & $\begin{array}{l}\text { The Burger makers } \\
\text { should take the } \\
\text { advantage of both } \\
\text { online as well as the } \\
\text { offline marketing in } \\
\text { Singapore. }\end{array}$ & $\begin{array}{l}\text { Being a new entry in } \\
\text { the highly } \\
\text { competitive market } \\
\text { of Singapore, the } \\
\text { company should set } \\
\text { its price range } \\
\text { cheaper than its } \\
\text { existing competitors } \\
\text { without affecting the } \\
\text { quality of the product } \\
\text { to attract consumers. }\end{array}$ & $\begin{array}{l}\text { Considering the fact } \\
\text { that the country is } \\
\text { technologically } \\
\text { advanced, Burger } \\
\text { Makers should } \\
\text { promote its product } \\
\text { through social media, } \\
\text { television, hoardings } \\
\text { and magazines. }\end{array}$ \\
\hline
\end{tabular}

\section{Swot Analysis Of Burger Makers}

What makes SWOT analysis influential and powerful for all of businesses is that, with a little thought, it can help in mapping resources with available opportunities. Hence, Burger Makers Company has to uncover opportunities and efficiently exploit it. By understanding the weaknesses, the company can be able to eliminate threats that might affect the company strategy.

Table 3: SWOT Analysis Of Burger Makers

\begin{tabular}{|c|c|c|c|}
\hline Strengths & Weaknesses & Opportunities & Threats \\
\hline $\begin{array}{l}\text { The quality of the } \\
\text { burgers and } \\
\text { French fries of } \\
\text { the Company } \\
\text { really good. } \\
\text { The company } \\
\text { provides a good } \\
\text { number of } \\
\text { variations of } \\
\text { burgers to } \\
\text { choose from. The } \\
\text { prices of the } \\
\text { products are } \\
\text { much cheaper } \\
\text { with respect to } \\
\text { its quality. }\end{array}$ & $\begin{array}{l}\text { Being a local company } \\
\text { of Jordan, the } \\
\text { company doesn't } \\
\text { have brand equity } \\
\text { (Whitton et al., 2014). } \\
\text { Being a new entry in } \\
\text { the fast food market } \\
\text { of Singapore, the } \\
\text { company will have } \\
\text { low consumer loyalty. } \\
\text { The company needs } \\
\text { to bring new items in } \\
\text { the menu list to cope } \\
\text { up with its consumers } \\
\text { in the international } \\
\text { market. }\end{array}$ & $\begin{array}{l}\text { Burger Makers can } \\
\text { increase its menulist } \\
\text { by incorporating } \\
\text { healthy products in } \\
\text { its menu list along } \\
\text { with adding more } \\
\text { fast-food products in } \\
\text { its menu list. } \\
\text { The company can } \\
\text { enhance consumer } \\
\text { loyalty and brand } \\
\text { equity by selling } \\
\text { quality food product } \\
\text { in a much cheaper } \\
\text { rate. }\end{array}$ & $\begin{array}{l}\text { The competitive } \\
\text { pressure in the } \\
\text { fast food industry } \\
\text { in Singapore is } \\
\text { high. Some of the } \\
\text { major competitors } \\
\text { of the company } \\
\text { are Burger King, } \\
\text { KFC and } \\
\text { McDonalds. } \\
\text { Another major } \\
\text { threat for the } \\
\text { company is the } \\
\text { inclination of the } \\
\text { citizens towards } \\
\text { healthy lifestyle. }\end{array}$ \\
\hline
\end{tabular}




\section{Strategic Planning Of International Marketing}

Creating a superior business doesn't mean just focusing on the organizations financial resources. Exploring the most sold products, improving products quality, reducte costs and ultimately finding the right segment and customers (Bataineh, 2017; Apgrianto, Pali, Handarini, \& Muslihati, 2018). International marketing communication campaigns, also known as advertising campaigns can be defined as actions and activities which are performed by the management of certain in order to promote a particular product or service in the international market. The mentioned campaign is done by spreading a particular massage through various promotional media that include print media, television, internet and others (Same and Larimo, 2012). The strategic plan for marketing communication campaigns are designed in a step by step order. Internal marketing Campaigns are not just about advertising the product or the company butt it includes tactics, exhibitions and various other techniques to make the consumers of the chosen international market aware of the product or the organization.

In order to plan an effective strategy of marketing communication in International market factors like cultural issues of the chosen international market, media choice for promotion of the business should be considered. Other factors that required to be considered while conduction an international marketing communication includes the following factors:

- Level of literacy of the consumers of the chosen market

- The diversity or similarity of religion, morality, beliefs, values and mortality of the targeted International market

- The economic status of the consumers in the chosen market.

- The work ethics of the employees of the chosen international market.

- Finally the role of the family members of the consumers should be taken to account.

An effective international communication model that can be used by an organization to develop International market communication strategies is the Marketing communication mix model. It is a specific mix of personal selling, advertising, sales promotion, public relation and direct marketing that an organization uses to pursue its marketing and advertising objectives. While advertising can be conducted through any paid form of presentation, promotion of ideas, services or goods by a specific sponsor, personal selling refers to personal presentation by the organization's sales force in order to serve the purpose of selling products and building effective company-consumer relationship. Sales promotion refers to a short term incentive that encourages the sell or purchase of any product or services (Berthon et al., 2012). Building good relationship with the consumers helps an organization to build a good corporate image that eventually results in increment in consumer loyalty. Finally, by direct marketing, an organization targets specific consumers to cultivate consumer-company relationship and obtain immediate consumer response. 


\section{Marketing Communications Strategic Approach}

Considering the fact that Burger Makers Company is approaching the Singaporean fast food market, it is really crucial for the company to plan an effective prelaunch campaign to successfully attract the attention of the fast food consumers of Singapore (Catherine Henderson, 2014). Considering the fact that Singapore is highly advanced technologically, the mentioned company will be able to conduct both online and offline campaigns. However, In order to create loyal and committed employees it is vital for organizations to apply various types of internal branding techniques, since the internal branding is an approach that measures the positive influence of organizations' brand on employees' thoughts, feelings and attitudes, which can lead them to respond in a particular way with the aim of reinforce brand building process (Bataineh and Alfalah, 2015).

The first step of conducting a pre-launch campaign by Burger Makers Company should involve creation of an effective landing page with special offers like free appetizer or a bye one get one free deal. Such offers will not only attract the consumers but will also ensure the promotion of the company. The landing page of the company should also contain an official video featuring the special range of fast foods items offered by the company. Apart from offering traditional fast food like McDonalds and Subway, Burger Makers should also feature conventional Jordanian fast foods like (Shawarma) in order to offer the fast food consumers of Singapore unique taste of Arab. Besides that, the landing page of the company should have detailed information about the nutrition values of the ingredients used in manufacturing the fast food items. This strategy will attract the health conscious consumers of Singapore. When it comes to promote the company through its launching page, visual appeal is something which shall not be compromised with. According to researchers, it is very crucial for organizations to create a visually attractive landing page since consumers will not spent more than 50 milliseconds to decide whether they are interested in the offerings made by the company or not (Kirby, 2012). Therefore Burger Makers shall include catchy headlines, attractive image, fun and attractive videos along with prominent call-to-actions to engage the visitors of the official page.

The next step of international pre-launch campaign of the Burger Makers Company should involve promotion of its products by conducting a social media campaign in popular social media cites like Facebook, Twitter and Instagram. Starting an online campaign through social media will not only help the management of the company to understand the requirements of the Singaporean consumers, it will also ensure formation and maintenance of a good consumercompany relationship. This strategy shall impose both short term and long term positive aspects on the company. While the short term benefits will involve promotion of the fast food items of the company through social media along with enhancement of the sales of the company, the long term benefits will involves enhancement of the brand equity and consumer loyalty of Berger Makers in the fast food industry of Singapore.

Considering the fact that the chief target consumers of the company are individual of age ranging from 10 to 50 years, it can be clearly understood that the only way to understand the interest and attract this huge range of consumer are to create powerful content and stir interesting conversation, According to statistics, businesses which are able to develop effective content 
marketing tactics, enjoys approximately 7.5 times more traffic compared to businesses which are not availing this facility (Rekhy and McConchie, 2014). Therefore, Burger Makers Company should engage professionals to create interesting contents and communicate effectively with the consumers to develop effective consumer-company relationship.

The third step of the pre-launch campaign will involve offline promotion campaigning by the Burger Makers Company. This promotional strategy shall involve surveys and competition which will be conducted among the fast food consumers of Singapore. In order to encourage Singaporean citizens to participate in the campaign, Burger Makers can offer gift coupons and free restaurant passes to the participants. This strategy will not only let the Singaporean consumer know about the existence of the company, it will also ensure immediate promotion of the Burger Makers company (Kapferer, 2012; Anghelache, Marinescu, Samson, 2018).

In addition to this, the company needs to make funny and attractive advertisement videos since these types of videos goes viral in social media in very less amount of time. One of the chief strategies of Burger Makers Company while composing a video shall be to redirect the consumers to its landing page. In order to promote its products and encourage consumers to visit the landing page of the Burgers Makers, the company can follow the pre-launch campaign strategy of McDonalds. McDonald's landing page went viral since it offered its visitors in exchange of referring to friends and family. The Burger Makers can also implement this strategy since these types of reward-based tactics are highly common in all successful pre-launch campaigns. The major advantage of this reward-based tactic is that these tactics are financially feasible and are capable of fetching immediate popularity.

The next step of pre-launch campaign shall involve advertisement of the company with the help of hoardings and posters throughout the country (Rice and Atkin, 2012). The advertisement slogan 'Health with Taste' shall put emphasis on the cheap price and high quality fast food items offered by the Burger Makers Company. The advertisement should also highlight the healthy meals offered by the company. This strategy will not only create awareness about the company among the fast food consumers of Singapore, it will also attract health conscious individuals since the one of the chief mottos of the company is to offer health with taste.

\section{Conclusion}

Fast food market is among the numerous segments that are extremely influenced by the fastpaced consumer's lifestyle, specifically the millennial generation. The young people are adventurous and food savvy, they highly tend to taste new products, consequently, the demand for various fast foods is growing. For that reason, most of countries keep a significant designation for fast food branding to expand cross borders. However, fast food brands are bringing into line with the changing consumer needs and trends. Nowadays, the fast food sector enjoys inescapable popularity worldwide and the upcoming future positively looks promising at this point. Globally, the consumption fast food has grown-up in the last two decades, creating a lot of opportunities for multi fast food brands. Market entry strategy reflects the process of planning and delivering of products to a new market. During planning there are many stages in which the whole process must to go through in order to reach the goals in the targeted segments such as 
target market characteristics, competition, sales forecasting and profits. It is a very risky step for companies to decide to enter new market, but at the same time is also considered a very bold tactic for a small company like burger makers because so many resources are being risked. To stay alive in the international market; burger makers must be prepared well for all the activities and adopt consumers trends and opportunities of international markets. However, some factors are related to the quality, quantity, labor, and cost of the raw materials, energy and other economic variables in the host country. These variables have extraordinary effect in making the entry mode decision (exporting, franchising, licensing etc.). Finally, international experience is also one of the most important factors which help in expanding overseas operations, entering new market and developing strong and long-term international business relations. From the above research, it can be concluded that, Singapore is a highly potential market to establish fast food business by the burger makers company. In order to gain success in the Singaporean fast food industry, Burger Makers should implement the above mentioned strategies to analyze the Singaporean market in detail. Finally by implementing the pre-launch Campaigning strategy, the company will be able to attract the Singaporean consumers and gain prosperity.

\section{Managerial Implications}

Burger makers company need to be aware of the following when deciding to enter this market: 1. Improve and emphasize hygienic practices and cleanliness in all activities performed in restaurant areas, including the restrooms. 2. Staff should be properly trained to deliver quality service. Performance standards should be set and staff trained to meet or exceed these standards. 3. Many customers had difficulty pronouncing and remembering the names of dishes, as they are written to phonetically equate to the sound of the words in Arabic. The company need to address this issue. They could translate all menu items into English where possible, and train servers to present them using both names; they could also provide a pronunciation guide in parentheses next to each dish, and instruct servers to present the dish using the Indian name (which helps retain authenticity). 4. Improve restaurant appearance by using the services of a professional interior designer, just as many other restaurants do. This will give them an edge over the competition. 5. Consistently control quality of food. Train kitchen staff in the importance of standardization of each dish, and maintenance of the same. 6. Set reasonable prices, and 7. Try to create positive word-of-mouth advertising by providing quality food and service.

\section{References}

1. Anghelache, C., Marinescu, A. I., Samson, T. (2018). Theoretical Characteristics of the Purchasing Power Parity in the EU Context, International Journal of Academic Research in Accounting, Finance and Management Sciences 8 (2): 37-47

2. Apgrianto, Y. Y., Pali, M., Handarini, D. M., \& Muslihati. (2018). The Effectiveness of Storytelling Method in Experiential Learning Model to Improve the Senior High School Students' Ability in Deducting Negative Stereotype. International Journal of Academic Research in Progressive Education and Development, 7(2), 86-95. 
3. Armstrong, G., Kotler, P., Harker, M., and Brennan, R. (2015). Marketing: an introduction. Pearson Education, pp.21-34.

4. Baker, M. J., and Saren, M. (2016). Marketing theory: a student text. Sage, pp.38-76.

5. Bataineh, A. (2017). "Determinants Of Relationship Continuity Between Sales Representatives And Pharmacists: The Mediating Role of Trust", the Journal of Applied Business Research, Vol, 33. No, 1. Pp. 57-66.

6. Bataineh, A., Alfalah, T. (2015). “Jordanians' Youths Brand Choice for Fashion Stores: The Mediating Role of Celebrity Endorsement", European Journal of Scientific Research, Vol, 134. No, 2. Pp. 194-205.

7. Bataineh, A., Alfalah, T. (2015). "The Role of Knowledge Management in Building Employees' Brand Commitment: Employees' Brand Knowledge as Mediating Variable", International Journal of Business and Social Science Vol. 6, No. 10.

8. Bataineh, A., Alfalah, T., Falah, J., Idris, M. (2017). "The Effect of Employee-Based Brand Equity on Organizational Citizenship Behavior: The Mediating Role of Job Satisfaction", International Journal of Academic Research in Business and Social Sciences, Vol, 7. No, 2. Pp. 423-436.

9. Berthon, P. R., Pitt, L. F., Plangger, K., and Shapiro, D. (2012). Marketing meets Web 2.0, social media, and creative consumers: Implications for international marketing strategy. Business horizons, 55(3), pp.261-271.

10. Czinkota, M. R., and Ronkainen, I. A. (2013). International marketing. Cengage Learning, pp.12-37.

11. E. Dobbs, M. (2014). Guidelines for applying Porter's five forces framework: a set of industry analysis templates. Competitiveness Review, 24(1), pp.32-45.

12. Gordon, R. (2012). Re-thinking and re-tooling the social marketing mix. Australasian Marketing Journal (AMJ), 20(2), pp.122-126.

13. Henderson, C. J. (2014). Food and culture: in search of a Singapore cuisine. British Food Journal, 116(6), pp.904-917.

14. Kapferer, J. N. (2012). The new strategic brand management: Advanced insights and strategic thinking. Kogan page publishers, pp.54-65.

15. Kirby, J. (2012). Viral marketing. Connected marketing, pp.87-106.

16. Rekhy, R., and McConchie, R. (2014). Promoting consumption of fruit and vegetables for better health. Have campaigns delivered on the goals?. Appetite, 79, pp.113-123.

17. Rice, R.E. and Atkin, C.K. eds., 2012. Public communication campaigns. Sage, pp.16-57.

18. Same, S., and Larimo, J. (2012). Marketing theory: Experience marketing and experiential marketing. In 7th International Scientific Conference "Business and Management (pp. 1011).

19. Shoter, A., Bataineh, A., Salhab, H. (2016) "Building a Model for Determining the Factors Affecting Mobile Marketing Acceptance and Adoption". International Review of Management and Business Research. Vol, 5. Issue, 3. Pp. 986-1007.

20. Solomon, M. R., Dahl, D. W., White, K., Zaichkowsky, J. L., and Polegato, R. (2014). Consumer behavior: Buying, having, and being (Vol. 10). Pearson, pp.34-56. 
21. Srdjevic, Z., Bajcetic, R., and Srdjevic, B. (2012). Identifying the criteria set for multicriteria decision making based on SWOT/PESTLE analysis: a case study of reconstructing a water intake structure. Water resources management, 26(12), pp.3379-3393.

22. Whitton, C., Ma, Y., Bastian, A. C., Chan, M. F., and Chew, L. (2014). Fast-food consumers in Singapore: demographic profile, diet quality and weight status. Public health nutrition, 17(8), pp.1805-1813.

23. www.worldbank.org

24. Yüksel, I. (2012). Developing a multi-criteria decision making model for PESTEL analysis. International Journal of Business and Management, 7(24), p.52. 